\title{
The Factors Affecting Profit Distribution: An Empirical Study on Islamic Banking
}

\author{
Tugiantoro, Suyanto \\ Trisakti University, Jakarta, Indonesia
}

\begin{abstract}
This paper has analysed the determinant factors of profit distributed to customers in Islamic banks. The research units are Bank Muamalat Indonesia, Bank Syariah Mandiri, and Bank Mega Syariah, since just these three Islamic banks meet this research's criteria. Five years data were used in this research, which is within the period of year 2006 to 2010. A descriptive correlation method is used to present the analysis result, while panel data method analysis was employed for the data analysis. This research shows that income from operation (IFO), central bank's (Bank of Indonesia) rate, and three-month term deposit rate in conventional banks significantly affect the profit distribution; while third parties' fund, Asset Quality Ratio (AQR), and Financing to Deposit Ratio (FDR) insignificantly affect the profit distribution. At confidence level of 95\%, the Adjusted R-Squared is $97.7 \%$, which indicates that the model is able to explain about $97.7 \%$ the affecting factors to the profit distribution and the remaining $2.3 \%$ explained by other variables, which is not included in this research.
\end{abstract}

Keywords: profit distribution, Islamic banking, conventional banking, unrestricted mudaraba

\section{Islamic Banking in Indonesia}

Islamic banking is banking activity that is consistent with the principles of sharia, which is based on the values and principles in the Quran and Hadith of the Prophet Muhammad (SAW). Sharia prohibits the fixed or floating payment or acceptance of specific interest or fees (known as riba or usury). Investing in the business that provides goods or services considered contrary to sharia principles is also haraam ("sinful and prohibited"). Sharia compliance finance is a more appropriate term for Islamic banking.

Although these principles have been applied in varying degree, the development of Islamic banking can be clearly seen started in the late 20th century during which a number of Islamic banks and sharia based financial institutions were established. Muslim community now able to establish a financial system is not based on interest. The financial activity principles in banking system are based on the risk-sharing (profit and loss sharing). The common sharia concepts in Islamic banking are mudharabah (partnership), musharakah (investment), murabahah (cost plus in purchase and sell of goods), qurud hasan (rate free finance and lease). These concepts are used in both business and consumptive financing.

The development of Islamic banks in Indonesia started in 1990s, no more than 20 branches and representative offices were available in that period. In 2005, one Islamic business unit and 13 Islamic rural

Tugiantoro,doctoral student, Department of Accounting, Trisakti University.

Suyanto, doctoral student,Department of Accounting, Trisakti University.

Correspondence concerning this article should be addressed toTugiantoro,Jl. Tanah Seratus No. 33 RT 006/004, Sudirmara Jaya, Ciledug-Banten, Indonesia 15151.E-mail: tugiantoro@yahoo.com. 
banks were established. As reported by Indonesia central bank, Bank of Indonesia, by August 2013, there are 11 Islamic commercial banks, 24 sharia business units, and 160 Islamic rural banks with total of 2,837 branches and representative office available all cross the country.

The development of Islamic banking in Indonesia is implemented in the dual banking system in compliance with the Indonesian Banking Architecture (API). Islamic banking and conventional banking systems jointly and synergically support a wider public fund mobilization in the framework of fostering financing capability of national economic sectors.

The characteristic of Islamic banking operation is based on partnership and mutual benefits principles provide an alternative banking system with mutual benefits both for the public and the bank. This system will give priorities to aspects related to fairness in transaction and ethical investment by underlining the values of togetherness and partnership in production, and by avoiding any speculative activity in financial transaction. By providing various products and banking services supported by varieties financial schemes, Islamic banking will be a credible alternative that can be benefited by all of Indonesian people without exception.

The enactment of Act NO. 21 of 2008 issued on July 16, 2008 has provided a more adequate legal base to the development of Islamic banking in Indonesia, and consequently, will accelerate the growth of the industry. With an impressive development progress reaching an annual average asset growth of more than $65 \%$ in the last five years, it is expected that Islamic banking industry will have more significant role in supporting national economy.

"The Blueprint of Islamic Banking Development in Indonesia” prepared by Indonesia Central Bank in 2002 provides guidance to stakeholders of Islamic banking and to set the position and vision of Indonesia Central Bank in developing Islamic Bank in Indonesia. In the process of preparing this Blueprint, various aspects have been taken comprehensively into consideration such as the actual condition of national Islamic banking industry including related tools, development trend of Islamic banking industry within international scale as well as system development of national Islamic finance that has started to be materialized and inseparable from wider architectural landscape such as Indonesian Banking Architecture (API) and Indonesian Financial System Architecture (ASKI) including international best practices formulated by International Islamic Financial Institutions such as Islamic Financial Services Board (IFSB), Accounting and Auditing Organization for Islamic Financial Institutions (AAOIFI), and The International Islamic Financial Market (IIFM).

Islamic banks as well as conventional banks have a role as an intermediary between surplus unit and deficit unit. They run fund gathering activities in the principles of deposit (wadiah) and profit sharing (mudharabah). While financing activities commonly are based on concept of purchase and sell (murabahah, salam and istishna), profit sharing (mudharabah and musharakah), leasing (ijarah and ijarah muntahiyya bittamlik).

Profit distribution to depositors under mudharabah contract is based on the revenue bank received in cash basis. This is in accordance with fatwa (legal pronouncement) of National Syariah Board of Indonesian Council of Ulama (DSN-MUI) as follows: Fatwa 14/DSN-MUI/IX/2000 concerning Distribution System of Profit Sharing in Finance Sharia of Institution (LKS) in principle stated that LKS may use accrual basis and cash basis in financial administration, in terms of welfare (al-ashlah), the recording system should use an accrual basis while the profit distribution should be in cash basis; fatwa 15/DSN-MUI/IX/2000 concerning Business of Profit sharing Distribution Principle in Finance Sharia of Institution stated that LKS may use the principle of net of revenue sharing or profit sharing in profit sharing distribution, in terms of welfare (al-ashlah), profit sharing distribution should use the net revenue sharing principles.

In concept mudharabah, monthly profit distribution is based on the IFO which bank earned from the 
financing activities. Financing activities include the lending, categorized as earning assets, which are the quality assets in the scheme of purchase and sell, profit sharing and leasing.

Concept of profit sharing in Islamic banks has to compete the interest concept in commercial banks. This research investigated the factor that determined the profit distribution in Islamic banks in Indonesia. Previous researches were conducted by Mawardi (2005) and Vustany (2006). This research is different to the earlier researches in terms of variables and period of research. Independent variables in this research are third party fund (TPF), IFO, AQR, FDR, central bank's (Bank of Indonesia) Rate/ BI Rate (Bir), and three-month term deposit rate in conventional banks.

\section{Theory and Hypothesis}

\section{Fund Management}

As an intermediary function, Islamic banks are raising funds from customers who have the excess fund and then distribute it to customers who require funds in the form of productive assets (earning assets). Islamic banks as well as the commercial banks are subject to the regulation of central bank (Bank of Indonesia) such as statutory reserve requirements, fulfilment of FDR, etc.. The difference of concept fund management in Islamic banks versus conventional banks is when receiving customer funds, conventional banks in advance agreed interest on deposits, as well as for the distribution of funds.

Islamic banks fund management concept is based on the capital approach (Siddiqi, 1983). Banks receive fund in form of deposits or profit sharing deposits. The funds then are distributed to the business in the form of earning assets. Banks are entitled to a share of profits raised from the bank financing, as agreed in the contract as a profit-sharing ratio. There are two approaches in raising and managing funds, which are pooled of fund approach and assets allocation approach. In the pooled of fund approach, funds are raised and distributed to earning assets; while in assets allocation approach, fund raised will be distributed according to the depositors' terms.

Karim (2006) divided fund allocation in Islamic banking on the certainty level of profit into two groups, natural certainty contract and natural uncertainty contract. Natural certainty contract is a contract with a business that provides certainty of payment in terms of both amount and time of payments. Businesses that included in this group are the purchase and sales agreement, wage contract, leasing, etc.. In natural uncertainty contracts, customers who run the business mix its assets (both real and financial assets) into a single entity, so that the risk and return are shared.

\section{Determination of Profit Margin and Profit Sharing From Financing}

Profit sharing for financing in natural certainty contracts, i.e. murabahah, salam, istishna, ijarah, and ijarah muntahiyya bittamlik, variables that affect the determination of the bank profit margins are: (1) direct competitor market rate: average profit margin of its nearest competitor, in terms of assets and targeted market; (2) indirect competitor market rate: average interest rate in conventional banks; (3) expected competitive return for investment: expected attributable profit sharing to TPF; (4) acquiring cost: cost incurred by bank which is directly related to the effort of fund raising from third parties; (5) overhead cost: cost incurred by the bank that are not directly related to the efforts to obtain third parties' funds (Karim, 2006); (7) risk: risk level of default in the distribution of funds; and (8) expected return: rate of return expected by the bank.

Profit sharing for financing in natural uncertainty contracts, i.e. mudharabah and musharakah, is determined with consideration factors: profit margin reference, forecasted profit margin of business financed (Karim, 2006) 


\section{Profit Distribution}

Determination of profit distribution to the customers of Islamic banks is based on the revenue received in cash basis. This profit distribution is applied for customers in unrestricted mudaraba by pooling fund according to the profit distribution table. Profit distribution to depositors is reported after revenue income in the income statement. Profit sharing to customers in restricted mudarababoth restricted mudaraba-executing (recorded to on-balance sheet) and restricted mudaraba-channeling (recorded to off-balance sheet) is presented in other operating income.

Profit sharing to customers based on the operating income is received in cash within a period (commonly on monthly basis), and distributed to customers under unrestricted mudaraba agreement. IFO is the income derived from the financing activities which are purchase and sale agreements, leasing, profit sharing, and other revenues, e.g. Islamic securities, Sharia Certificates of Bank Indonesia (SBIS), Government sharia securities (SBSN), and placement in other banks.

Factors that affect the profit sharing consist of directs factor: investment rate, funds available to invest, and ratio; and indirect factors: revenue and costs of mudharabah, and accounting policies (Antonio, 2001). Wiroso (2005) stated that profit distribution was determined by source of fund proportion, financing types and return earned, attributable income for profit sharing, foreign exchange classification, agreed ratio, and accounting policies.

This research analyzed the factors that determine the profit distribution to depositors under unrestricted mudaraba agreement. Banks use pooled of fund approach in the financing, and are allocated to earning assets, income is received on cash basis and distributed to depositors according to the ratio in the agreement. Income statement, named revenue and profit sharing reconciliation report, will be prepared at the end of accounting period. In this report, income is recognized in accrual basis while profit distribution to customers is based on revenues received in cash basis. Table 1 below shows profit distribution calculation in pooled of fund approach.

Table 1

Profit Distribution Table

\begin{tabular}{|c|c|c|c|c|c|c|c|}
\hline \multirow{4}{*}{ Fund Types } & \multirow{2}{*}{$\begin{array}{l}\text { Average } \\
\text { daily } \\
\text { balance }\end{array}$} & \multirow{2}{*}{$\begin{array}{l}\text { Attributable } \\
\text { Operating } \\
\text { Income }\end{array}$} & \multicolumn{3}{|c|}{ Depositors' Portion } & \multicolumn{2}{|c|}{ Bank’s Portion } \\
\hline & & & Ratio & Income & Return & Ratio & Income \\
\hline & $\mathrm{A}$ & $\mathrm{B}$ & $\mathrm{C}$ & $\mathrm{D}$ & $\mathrm{E}$ & $\mathrm{F}$ & G \\
\hline & (Rp) & $\mathrm{A} 1 / \sum \mathrm{A} \times \sum \mathrm{B}$ & $(\%)$ & $\mathrm{B} \times \mathrm{C}$ & $\mathrm{D} / \mathrm{A} \times 100 \% \times 12$ & $100-\mathrm{C}(\%)$ & $\mathrm{B} \times \mathrm{F}$ \\
\hline \multicolumn{8}{|l|}{ Source of Fund: } \\
\hline $\begin{array}{l}\text { Wadiah: } \\
\text {-Checking account } \\
\text {-Saving account }\end{array}$ & $\begin{array}{l}\text { A1 } \\
\text { A2 }\end{array}$ & $\begin{array}{l}\mathrm{A} 1 / \sum \mathrm{A} \times \sum \mathrm{B} \\
\mathrm{A} 2 / \sum \mathrm{A} \times \sum \mathrm{B}\end{array}$ & $\begin{array}{l}\mathrm{C} 1 \\
\mathrm{C} 2 \\
\end{array}$ & $\begin{array}{l}\mathrm{B} 1 \times \mathrm{C} 1 \\
\mathrm{~B} 2 \times \mathrm{C} 2 \\
\end{array}$ & $\begin{array}{l}\mathrm{D} 1 / \mathrm{A} 1 \times 100 \% \times 12 \\
\mathrm{D} 2 / \mathrm{A} 2 \times 100 \% \times 12\end{array}$ & $\begin{array}{l}100-\mathrm{C} 1 \\
100-\mathrm{C} 2 \\
\end{array}$ & $\begin{array}{l}\mathrm{B} 1 \times \mathrm{F} 1 \\
\mathrm{~B} 2 \times \mathrm{F} 2 \\
\end{array}$ \\
\hline $\begin{array}{l}\text { Mudharabah: } \\
\text { Checking Account }\end{array}$ & A3 & $\mathrm{A} 3 / \sum \mathrm{A} \times \sum \mathrm{B}$ & $\mathrm{C} 3$ & $\mathrm{~B} 3 \times \mathrm{C} 3$ & $\mathrm{D} 3 / \mathrm{A} 3 \times 100 \% \times 12$ & $100-\mathrm{C} 3$ & $\mathrm{~B} 3 \times \mathrm{F} 3$ \\
\hline $\begin{array}{l}\text { Saving Account } \\
\text { Term Deposit: }\end{array}$ & A4 & $\mathrm{A} 4 / \sum \mathrm{A} \times \sum \mathrm{B}$ & $\mathrm{C} 4$ & $\mathrm{~B} 4 \times \mathrm{C} 4$ & $\mathrm{D} 4 / \mathrm{A} 4 \times 100 \% \times 12$ & $100-\mathrm{C} 4$ & $\mathrm{~B} 4 \times \mathrm{F} 4$ \\
\hline-1 month & A5 & $\mathrm{A} 5 / \sum \mathrm{A} \times \sum \mathrm{B}$ & C5 & $\mathrm{B} 5 \times \mathrm{C} 5$ & $\mathrm{D} 5 / \mathrm{A} 5 \times 100 \% \times 12$ & $100-\mathrm{C} 5$ & $\mathrm{~B} 5 \times \mathrm{F} 5$ \\
\hline-3 months & A6 & $\mathrm{A} 6 / \sum \mathrm{A} \times \sum \mathrm{B}$ & C6 & $\mathrm{B} 6 \times \mathrm{C} 6$ & $\mathrm{D} 6 / \mathrm{A} 6 \times 100 \% \times 12$ & $100-\mathrm{C} 6$ & $\mathrm{~B} 6 \times \mathrm{F} 6$ \\
\hline-6 months & A7 & $\mathrm{A} 7 / \sum \mathrm{A} \times \sum \mathrm{B}$ & $\mathrm{C} 7$ & $\mathrm{~B} 7 \times \mathrm{C} 7$ & $\mathrm{D} 7 / \mathrm{A} 7 \times 100 \% \times 12$ & $100-\mathrm{C} 7$ & B7 $\times$ F7 \\
\hline-12 months & A8 & $\mathrm{A} 8 / \sum \mathrm{A} \times \sum \mathrm{B}$ & $\mathrm{C} 8$ & $\mathrm{~B} 8 \times \mathrm{C} 8$ & $\mathrm{D} 8 / \mathrm{A} 8 \times 100 \% \times 12$ & $100-\mathrm{C} 8$ & $\mathrm{~B} 8 \times \mathrm{F} 8$ \\
\hline Total & $\sum \mathrm{A}$ & $\sum \mathrm{B}$ & & $\sum \mathrm{D}$ & & & $\sum \mathrm{G}$ \\
\hline
\end{tabular}


The assumptions can be made as the following:

HA1: TPF has a positive impact on profit distribution.

HA2: IFO has a positive impact on profit distribution.

HA3: AQR has a positive impact on profit distribution.

HA4: FDR has a positive impact on profit distribution.

HA5: Central Bank Rate has a positive impact on profit distribution.

HA6: Three-month term deposit rate in conventional banks has a positive impact on profit distribution.

\section{Research Design}

\section{Research Framework}

Dependent variable in this research is profit distribution to customer under unrestricted mudaraba agreement (PDIST), while the independent variables are TPF, IFO, AQR, FDR, Bir, and three-month term deposit rate in conventional banks (i). This research is aimed to find out the effects of independent variables to dependent variable, either individually or all together simultaneously as shown in Figure 1.

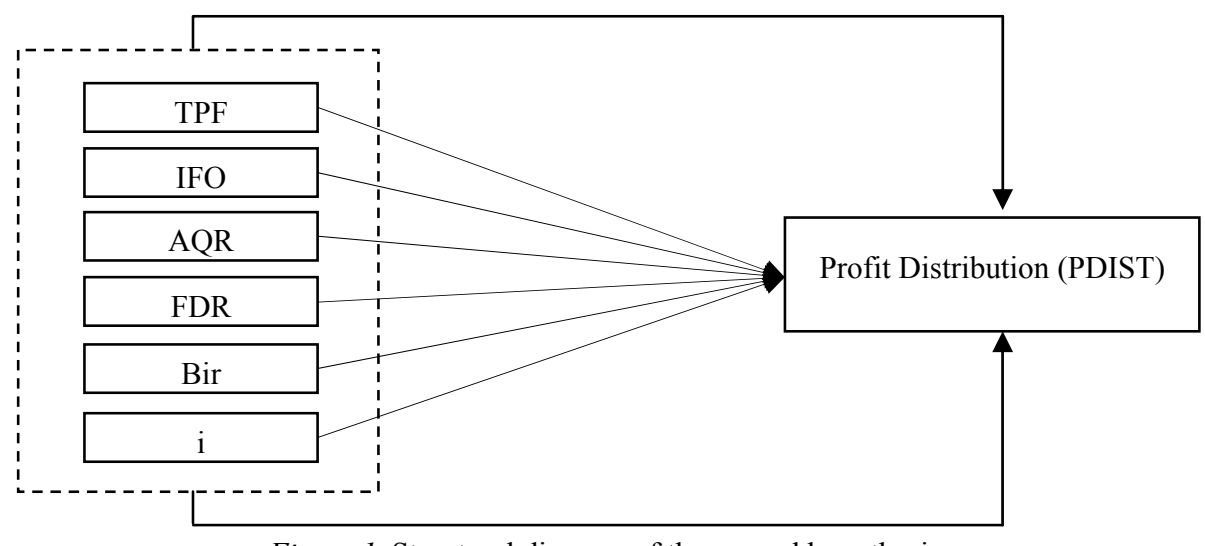

Figure 1. Structural diagram of theory and hypothesis.

\section{Research Method}

\section{Research Subject}

The method used in the research is purposive sampling method, with some considerations (judgment sampling). Therefore, the sample selection is not random selection but by certain considerations, usually adjusted to the purpose or research issues (Indriantoro \& Supomo, 2002, p.131). The sample should meet criteria: Indonesian Sharia Commercial Banks, which operate under the sharia law as a whole, and data used in this research are within period from 2006 to 2010. The justification is that the Islamic banks which met these criteria: Firstly, they are managed independently, if there were any shortage or excess fund, it will be settled by borrowing or financing or placement to third parties, while in Islamic business units, fund management is controlled by the holding which are conventional banks; secondly, profit distribution mechanism is based on the revenue received in cash, which is derived from the earnings assets, while in the Islamic business units, the holdings often subsidize the profit distribution in order to increase competitiveness, especially when the earning assets relatively considered in amount.

Based on these criteria Islamic banks that are fitted to this research were Bank Muamalat, Bank Syariah Mandiri, and Bank Mega Syariah. Data source is secondary data derived from the data published by Bank of 
Indonesia regarding to Islamic banks in Indonesia from January 2006 until December 2010 as well as the Bir, three-month term deposit rate.

\section{Correlation and Multiple Regression}

The method of analysis used is factor analysis, which tested the variables that indicated that it has influence over profit distribution under unrestricted mudaraba agreement. Correlation and multiple regression analyses are applied to show the strength of the variables' relationship. Then the model used for this empirical analysis is:

$\mathrm{PDIST}=f(\mathrm{TPF}, \mathrm{IFO}, \mathrm{AQR}, \mathrm{FDR}, \mathrm{Bir}, i)$, where:

PDIST : Profit Distribution to customers under unrestricted mudaraba agreement.

TPF : Third Parties funds

IFO : income from operation: income derived from the earning assets.

AQR : Asset Quality Ratio

FDR : Financing to Deposit Ratio

Bir : BI rate

Panel data is employed in this research. Panel data (Pooled Data) is a combination of time series and cross section data. Regression model for this research is:

$$
P D I S T=\beta_{0}+\beta_{1} T P F+\beta_{2} I F O+\beta_{3} A Q R+\beta_{4} F D R+\beta_{5} B i r+\beta_{6} i+\mu_{i t}
$$

\section{Results}

There are 180 observations in this research. From Table 2 shown below, profit distribution to customers under unrestricted mudaraba agreement ranges from IDR9,278 million to IDR1,188,913 million with average IDR271,466.2 million and median IDR185,755 million.

Table 2

Descriptive Statistic

\begin{tabular}{llllll}
\hline Variable & $N$ & Mean & Median & Maximum & Minimum \\
\hline PDIST & 180 & $271,466.2$ & 185,733 & $1,188,913$ & 9,278 \\
TPF & 180 & $8,673,109$ & $7,861,785$ & $28,671,278$ & 604,989 \\
IFO & 180 & $651,693.9$ & 524,576 & $2,838,357$ & 9,100 \\
AQR & 180 & 3.582778 & 3.815 & 7.39 & 0.52 \\
FDR & 180 & 93.22917 & 92.875 & 127.12 & 73.83 \\
Bir & 180 & 8.55 & 8.25 & 12.75 & 6.5 \\
i & 180 & 9.047667 & 8.305 & 12.55 & 6.93 \\
\hline
\end{tabular}

In panel data analyses, data is stacked cross-sectional and time series from January 2006 to December 2010. The result using original data shows unsatisfied results. Therefore the data is transformed by first differential and natural logarithm. The chow test results that either $F$ test or Chi-square is insignificant $(p$-value $>0.05)$ then the model went to pooled model. The results of pooled model analyses are shown in the Table 3 .

Under the classical assumption test, there are no issues of multicollinearity, heteroskedasticity, and autocorrelation. Adjusted $R$-Squared of $97.7 \%$, this indicates that the model is able to explain $97.7 \%$ of the actual conditions and this model is reliable, and it also shows strong correlation between dependent and 
independent variables. The $F$ test result of 1241.583 with probability $<0.05$ shows that the independent variables all together simultaneously significantly influence the dependent variable.

Table 3

Result of Pooled Model

Dependent Variable: DLOG((BAGHAS))

Method: Panel Least Squares

Date: 07/19/11 Time: $02: 16$

Sample (adjusted): 2006M02 2010M12

Periods included: 59

Cross-sections included: 3

Total panel (balanced) observations: 177

\begin{tabular}{|c|c|c|c|c|}
\hline Variable & Coefficient & Std. Error & $t$-Statistic & Prob. \\
\hline $\mathrm{C}$ & 0.342965 & 0.373307 & 0.918722 & 0.3595 \\
\hline DLOG(TPF) & 0.091379 & 0.131007 & 0.697515 & 0.4864 \\
\hline DLOG(IFO) & 1.020359 & 0.012171 & 83.83218 & 0.0000 \\
\hline DLOG(AQR) & 0.016271 & 0.047993 & 0.339023 & 0.7350 \\
\hline LOG(FDR) & -0.080239 & 0.082353 & -0.974331 & 0.3313 \\
\hline DLOG(BIR) & -1.112764 & 0.437628 & -2.542714 & 0.0119 \\
\hline DLOG(I) & 0.884115 & 0.301167 & 2.935631 & 0.0038 \\
\hline$R$-squared & 0.977689 & \multicolumn{2}{|c|}{ Mean dependent var } & 0.051881 \\
\hline Adjusted $R$-squared & 0.976901 & \multicolumn{2}{|c|}{ S.D. dependent var } & 0.668412 \\
\hline S.E. of regression & 0.101587 & \multicolumn{2}{|c|}{ Akaike info criterion } & -1.697061 \\
\hline Sum squared resid & 1.754381 & \multicolumn{2}{|c|}{ Schwarz criterion } & -1.571450 \\
\hline Log likelihood & 157.1899 & \multicolumn{2}{|c|}{ Hannan-Quinn criter. } & -1.646118 \\
\hline$F$-statistic & $1,241.583$ & \multicolumn{2}{|c|}{ Durbin-Watson stat } & 2.054105 \\
\hline $\operatorname{Prob}(F$-statistic $)$ & 0.000000 & & & \\
\hline
\end{tabular}

Partial test ( $t$ test) analyzed the influence of each independent variable on the other dependent variables. Significance level $<0.05$ resulted as indication that the independent variable has significant impact on the independent variable. The growth of IFO, Bir, and three-month term deposit rate in conventional banks has value of the $t$-statistic $<0.05$, which means that these variables have a significant effect on independent variables. The growth of third parties fund, AQR, and FDR has value of $t$-statistic $>0.05$, therefore these variables have insignificant influence on the independent variable. Regression model derived from the test results is as follows:

$$
\begin{aligned}
D L O G(P D I S T) & =0.343+0.092 D L O G(T P F)+1.020 D L O G(I F O)+0.016 D L O G(A Q R) \\
& -0.080 D L O G(F D R)-1.113 \text { DLOG }(\text { Bir })+0.884 D L O G(i)+\mu_{i t}
\end{aligned}
$$

The results show that the growth of the IFO affected the profit distribution to customers. This result is inline with the result of previous researches by Vustany (2006) and Karim (2006)'s statement. Antonio (2001, p.139-140) stated that income and cost item determination factors determine the profit distribution. A contrary result from research by Mawardi (2005) may cause the lesser number of sample and period used in his research that are one institution within June 2002 to December 2004. IFO is income derived from financing activities in the form of earning assets, the larger amount of IFO, and the larger amount of attributable income to depositors.

The growth of AQR does not affect the profit distribution, which is consistent with previous research by Mawardi (2005) that the Non-Performing Financing (NPF) does not have effect on profit distribution to customers. NPF in Mawardi's research is the AQR in this research. 
Consistent with previous research by Mawardi (2005) and Karim's statement that financing to debt ratio is one of the factors that determine the profit distribution, this research shows that the growth of FDR has insignificant impact on the profit distribution. This is, FDR is a ratio of financing and third parties' fund, if FDR is equal to $100 \%$, then it means all financing sources are from third parties' fund and the income from financing will be distributed to its customers. If the FDR $>100 \%$, therefore besides third parties' fund, other sources of the fund also were used in the financing activities, e.g. its equity. If FDR ratio $<100 \%$, this means that third parties' funds were not only used in financing activities but also in others earning assets such as securities, SBIS, SBSN, placement in other banks. Profit attributable to customer was derived from both financing and non-financing earning assets.

The results of this research showed that the growth Bir affected profit distribution to customers. This is consistent with previous research by Vustany (2006) that the Bir affected the profit distribution to customers. Bir is determined by the monetary authority (central bank) through its Board of Governors meetings. Bir is expected to create a healthy competition among the banks, since Bir is a base for conventional banks in determining the pricing for term deposit. Islamic banks compete each other and compete the conventional banks, then Bir is a factor that will affect the ratio of profit distribution.

The research showed us that the growth of three-month term deposit rate of conventional banks affected the profit distribution. This is consistent with previous research by Haron and Ahmad (2000) that profit motif is a primary factor that encourages customers of Islamic banks in Malaysia to deposit their fund. Also it's consistent with research by Mawardi (2005) that the one-month term deposit rate in conventional banks affected the profit distribution. However, this result is not in line with the result of research by Vustany (2006). This can be derived since the sample used in his research is one institution, Bank Mualamat, with 12-month term deposit rate in conventional banks.

Periods of term deposit generally are one month, three months, six months, and 12 months. In addition to determining pricing based on the Bir, the internal factors of each bank are also considered in the calculation. If conventional banks' deposit rates are considered as a factor for profit distribution, it could cause a moral hazard of Islamic banks in distributing the profit; bank might distribute income to customers which should be the portion attributable to the bank or vice versa. Islamic banks should have a higher competitiveness in terms of return received by the customers. From the customers' point of views, it is the banks' responsibility to manage the fund according to the contract agreed.

\section{Conclusions}

The main aim of this paper is to examine the factors that determine the profit distribution in Islamic banks. The hypothesis is that third parties' fund, IFO, quality assets ratio, financing to debt ratio, Bir, and time deposit interest rate in conventional banks will affect the profit distribution. This research employed data from 2006 to 2010. Bank Muamalat Indonesia, Bank Syariah Mandiri, and Bank Mega Syariah are the research units. This study estimated the model using a panel data approach.

Simultaneously the independent variables are significantly the dependent variable. Partially, the growth of IFO, Bir, and three-month term deposit rate in conventional banks has significant effect on independent variables. While the growth of third parties' fund, AQR, and FDR has insignificant influence on the independent variable. Adjusted $R$-Squared of $97.7 \%$ indicates that the model is able to explain $97.7 \%$ of the actual conditions and this model is reliable, and it also shows strong correlation between dependent and 
independent variables. While the remaining $2.3 \%$ is explained by other factors which are not included in this research. This indicates that Islamic banks should maintain the income form operation in order to maintain the profit sharing distribution to the depositors.

To obtain maximum results, further research may be needed with a wider respondent data, or a comparison with other countries abroad.

\section{References}

Antonio, M. S. (2001). Islamic banking from theory to practice (Bank syariah dari teori ke praktek). Jakarta: Gema Insani Press.

Haron, S., \& Ahmad, N. (2000). The effects of conventional interest rates and rate of profit on funds deposited with Islamic banking system in Malaysia. International Journal of Islamic Financial Services.

Indriantoro \& Supomo (2002).Business research method (Metodologi Penelitian Bisnis). Yogyakarta: BPFE.

Karim, A. A. (2006). Islamic Banking: Analysis of Financial and Jurisprudence (Analisis Fiqih dan Keuangan). Jakarta: Raja Grafindo Persada.

Mawardi, N. (2005). The Factors Affecting Return of Unrestricted Mudaraba Time Deposit (Faktor-faktor yang Mempengaruhi Penetapan Return Bagi Hasil Deposito Mudarabah Muthlaqah). University of Indonesia.

Siddiqi, M. N. (1983). Issues in Islamic Banking. Journal of Research in Islamic Economics, 57-59.

Vustany, O. R. (2006). The factors influencing return to depositor (Faktor-faktor yang Mempengaruhi Pemberian Bagi Hasil nasabah). University of Indonesia.

Wiroso. (2005). Fund gatheringand profitdistribution in Islamic banking (Penghimpunan dana dan distribusi hasil usaha bank syariah).Jakarta: Grasindo. 